\title{
Transitional justice and democratic consolidation in post-communist Eastern Europe: Romania and Albania
}

\author{
Ilir KALEMAJ*
}

\begin{abstract}
While there are many studies on the democratization trajectory of former communist countries of Eastern Europe, only a few of them have a particular focus on how transitional justice helps democratic consolidation. The present comparative study seeks to fill that gap by focusing specifically on the cases of Romania and Albania, situating them in the wider kaleidoscope of former Eastern Europe. Some of these countries have had a fast implementation of transitional justice measures and successful democratization. Yet, despite adopting an early mechanism of transitional justice, others did not necessarily have any particular success in their democratic endeavour. On the other hand, additional states have had democratic consolidation despite not undertaking such rapid measures (for example Estonia), while others have failed either to adopt the transitional justice mechanisms or democratizing at all (i.e., Belarus). The present paper offers a theoretical framework that seeks to capture and explain such dynamics and by referring specifically to the telling cases of Romania and Albania, to explain what role and impact transitional justice measures have in democratic transitions.
\end{abstract}

Keywords: transitional justice, democratic consolidation, Eastern Europe, Romania, Albania

\section{Introduction}

Transitional justice is a conditio sine qua non for dealing with an authoritarian past and enabling a fast transition toward rule of law and democratic consolidation. The existing literature on how transitional justice measures affect the democratization trajectory of former communist regimes in Eastern Europe is rather underdeveloped (Horne, 2017; Halmai, 2009; de Brito et al., 2001). Three decades after the fall of communist systems and with a handful of states still caught in a protracted transition or being unconsolidated democracies, this nexus needs to be

\footnotetext{
* Ilir KALEMAJ is Associate Professor at Department of Political Science/International Relations, University of New York Tirana, Tirana, Albania; e-mail: ikalemaj@unyt.edu.al.
} 
further explored and the present article seeks to fill this particular gap. Therefore, it starts with the puzzle of how the implementation of various transitional justice measures impacts democratic consolidation. The initial hypothesis is that fast implementation in an early post-dictatorship stage of transitional justice measures should result in successful democratic consolidation.

There is extensive literature about democratization in general that includes the transition processes in post-communist Eastern European countries in particular. Meanwhile, the speed and nature of their transitions have varied greatly. Simultaneously, we have a growing but significant scholarship in transitional justice in former communist countries, focusing on how these countries are dealing with their authoritarian pasts. However, this is still an emergent field of study and much has to be done to uncover stories, collect data and develop analytical tools to help us critically understand the effects of individual and collective trauma and how to address them.

But what remains crucially under-researched is the link between the two phenomena. In effect, we need to know more about how success or failure to implement early on transitional justice measures has affected the shape and success of democratic consolidation. The present study seeks to address this missing link and, after an overview of the state of affairs in former communist countries, it focuses particularly on Romania and Albania.

Therein, the paper seeks to provide an answer as to how a lack of full accountability for totalitarian regime crimes has resulted in problematic democratization for Albania in the post-communist period. The Albanian case will be analysed vis-à-vis the Romanian one, which, despite sharing many similarities with Albania, differs in the crucial aspect of the role played by transitional justice measures that were successfully implemented and led to democratic consolidation.

Here I focus on introducing some of the relevant debates that relate to the speed of transitions and the present-day shape of democracies in post-communist space. By also discussing the implementation of transitional justice measures and how they have impacted these transitions, we can fill an important gap and contribute to existing debates in the field. Therefore, I start with a brief introduction of transitology debates that set up the framework of my discussion. My dependent variable is democratic consolidation and the shape and speed of transitions in former Eastern Europe generally, Albania and Romania in particular. While there is, abundant literature that discusses Romania's implementation of transitional justice measures and how they have impacted its democratization (i.e., Stan, 2013; 2014; Grosescu, 2017), information on the Albanian case is scarce (Elbasani and Lepinski, 2011), notwithstanding their similarities in other regards.

I identify as independent variables the transitional justice measures, the implementation of which shape the prospects for democratic consolidation. The paper also deals with how transitional justice has affected democratic consolidation in post- 
communist countries. I construct a typology that helps us understand where different countries in the region fit, before focusing particularly on Romania and Albania.

To test the arguments being hypothesized here, the article uses Mill's Method of Difference (Mill, 1843, p. 455), which enables us to understand why given the similarity of communist pasts between Albania and Romania, their brutal ends of communist regimes and other common trends at the beginning of the democratic transition, Romania seems to have introduced more successful transitional justice measures, which in turn have enabled Romania's democratic consolidation, while Albania failed to do so.

My findings show that the success of the transition and democratic consolidation relies to a large degree on what transitional justice mechanisms have been adopted, how they were implemented, and with what effect. Although they do not show evidence of a direct causal effect of the implementation of transitional justice on democratic consolidation, there is a correlation between the speed of transitional justice adoption and successful democratization. Adopting transitional justice measures quickly leads to faster democratic consolidation.

Organizationally, the paper first gives an overview of the main debates in democratization studies, by focusing chiefly on CEE countries and their transitions from communist dictatorships. Then, it focuses on contemporary debates on transitional justice measures, particularly how they have been implemented in the former communist countries of Eastern Europe. It continues with case-selection justification and a typology that helps us understand the framework of CEE countries when measured in how effective the transitional justice mechanisms have been to help these countries transition to consolidated democracies that enforce the rule of law.

Lastly, it focuses on the cases of Romania and Albania. It first discusses what transitional justice measures have been in place and how they have affected these two countries' transition trajectories. While there is significant scholarship on Romania, the Albanian case is rather unexplored and has much to offer as an archetypical state in our understanding of how transitional justice measures affect the shape of democratization in post-totalitarian societies. In a nutshell, although both Romania and Albania had many similarities, they implemented with different degrees of success their transitional justice measures, which in turn led to different democratization paths.

\section{Literature review}

\subsection{Transitology and considology debates in eastern Europe}

Much has been written on transitions to democracy and why they are relevant for the health of a functioning society. Democracy studies go back to Schumpeter (1942) and Dahl (1971) where he essentially noted "eight requirements for a Democracy among a Large Number of People." Other authors have added a couple 
of other essential ingredients, such as political accountability and the rule of law (Brown, 1999). Both are important for my argument of how transitional justice mechanisms help to strengthen them respectively. Early transitology studies focused on immediate and unconditional transitions from dictatorships to consolidated democracies (Huntington, 1993; O'Donnell et al., 1986). This was done through ruptures of the former regime or through an initial pact, as the cases of Southern Europe in the late 1970s demonstrated (Stepan and Linz, 1996). Also, they focused on regime transformation following authoritarian rule and how the new emerging regime was unabashedly pro-democracy. As a matter of fact, these early expectations did not correspond to transitions from authoritarian rule in Latin America where pacts were difficult to achieve and often transitions did not go smoothly (Stepan and Linz, 1996). The significance of the mode of transitions translated into the shape of democratic consolidation or lack thereof. In some cases, there was a return to authoritarian rule, as in the case of Belarus, for example (Kuzio, 2002).

These early transition hypotheses were revisited after the events in postcommunist CEE, where transitions took various shapes and democratization trajectories varied from case to case. While the importance of economic performance for democratization was noted early on (Lipset, 1959), the strong causal relationship between economic well-being and the chances of success of democratization took new relevance in post-communist Eastern Europe. While some were cases of rapid economic overturn achieved through "shock therapy", others had a more gradual economic transformation such as Slovenia. Nonetheless, they were equally successful when it came to completing an early political transition toward democratic consolidation and the establishment of the rule of law. This was no doubt helped to a large degree by a firm rupture from communist regimes, which was made possible through the quick implementation of transitional justice mechanisms, such as trials and lustration processes in the Czech Republic and East Germany.

In other cases, including Albania and Serbia, countries got caught in a difficult and prolonged transition, although for different reasons. In Albania, the chief problem was a highly fractured elite and prolonged political warfare, while in Serbia it was the irredentist ethnic wars led by Milosević's regime in his attempt to carve a "Greater Serbia" out of a rump Yugoslavia. Yet, in other cases, such as Ukraine and Belarus, the transition went backward, with Belarus returning quickly to authoritarian rule (Kuzio, 2002). Thus, former communist Eastern Europe offers various trajectories to democratic consolidation that have opened up new avenues of research.

Initially, authors such as O'Donnell and Schmitter (1986) focused on the importance of political leadership decision-making and reforms of the legal and institutional framework in trying to establish the rule of law. Also, of great importance for the transitional justice debate today, was their impact on exploring the past and how that was conducive to democracy. This matter because the end goal of the transition process is to reach the stage of democratic consolidation, which for 
authors such as Stepan and Linz is the "clear hierarchy of laws, interpreted by an independent judicial system and supported by a strong legal culture in civil society" (Linz and Stepan, 1996, p. 10). The literature on transitology thus filled an important vacuum in the study of democratization. Whereas prior theories in the field focused on structural factors like socio-economic conditions for understanding the transition, with time, transitology opened the door for the introduction of top-down, elite-driven models that led to new transitions. ${ }^{1}$

The more recent debates focus on how a combination of comparative politics with area studies specialists (Saxonberg and Linde, 2003) help to balance a deep knowledge of the idiosyncrasies of specific cases with an appreciation of the wider context for democratization. In addition, some recent studies have tested hypotheses that link the transition trajectories with transition outcomes, in terms of success and failure (Guo and Stradiotto, 2014). Other authors have demonstrated that whenever there is a kind of elite pact, democracies are stronger and last longer (Stepan and Linz, 1996). Pioneering works (Lipset, 1959) have noted on the other hand a strong causal connection between economic well-being and chances of success of democratization. Both of these preconditions are affirmed time and again in the most recent literature (Acemoglu, 2014). It also is important to keep in mind that, if fragile democracies are to have a shot at consolidation, they should develop strong institutions and become more accountable, as Larry Diamond (1999) reminds us.

Furthermore, it matters how transitology and democratization studies take into account the newly emerging sub-fields, such as transitional justice. Below, I give a short overview of the main conceptual debates in transitional justice, to be followed by how it has been implemented in post-communist countries and how this can help us understand successful transitions and democratic consolidation.

\subsection{Debates in contemporary transitional justice}

The transitional justice field has long been interested in dealing with the past effects of democratization. From the early days, debates have raged between retributivists who argue for criminal prosecution following mass violations of rights (i.e., Drumbl, 2007) and restorationists who rely mostly on "soft" ways of dealing with the past, such as truth-telling (Teitel, 2002; Wiebelhaus-Brahm, 2010). Yet, others have also added reparative conceptions of justice alongside the others (Muddell and Hawkins, 2018).

\footnotetext{
${ }^{1}$ Other authors have criticized the dichotomy between consolidated versus non-consolidated democracies (Merkel, 1998), focusing instead on different layers that range from constitutional framework to civic culture, but I find this overly broad and fuzzy. Also, other scholars have criticized the consolidated democracy terminology as an overstretched concept that suffers from diffusion (Schelder, 1998). Here, I follow O'Donnell (1996) in defining it as a democracy that matures to the point where it is impossible "to revert to authoritarianism without an external shock".
} 
A common thread in most transnational justice debates is that the end goal is a consolidated democracy that closes the wounds of the past. Without a transition cycle that includes the need to address past injustices, most scholars in the field (i.e., Arnould and Sriram, 2014; Magara, 2016), rightly believe that we cannot safely assume to have reached the stage of a consolidated democracy.

State leaders are often held accountable through retributive mechanisms like criminal prosecutions and to a lesser extent and indirectly through restorative mechanisms like truth commissions. The definition of transitional justice remains contested, but, in general, it refers to the legal and non-legal mechanisms that states undertake after gross violations of individual and collective rights from the previous regime. These mechanisms include but are not limited, to inter alia, criminal prosecutions, truth commissions, reparations, lustration, apologies, memorials, institutional reform, etc. The early focus of the field was on questions of leadership and mass accountability in democratic transition. According to Ní Aoláin and Campbell (2005), this made possible the framing of transitional justice as a coherent set of narratives and discourse, which provided the framework for the field in the future. Later on, the focus expanded and included also other aspects such as reparations and truth-telling, reconciliation, forgiveness, healing, etc. (Stover and Weinstein, 2004; Borer, 2006).

The debate between the need for trials as the primary weapon of dealing with the past versus truth commissions was one of the yet unsolved dilemmas of scholars engaging with transitional justice in democratizing societies (Hayner, 2002; Aukerman, 2002). This constituted essentially the core debate between retributive restorative justice. On the other hand, from an empirical perspective, some authors have convincingly demonstrated that truth commissions have little impact on democracy (Wiebelhaus-Brahm, 2010). This opens up new avenues of research because it seems to discard the effect that some particular measures of transitional justice have much impact on democratic consolidation. Therefore, we might assume that early and successful implementation of transitional justice measures does not necessarily impact, rapid democratization. Yet, other measures do seem to affect it, like early trials or processes of lustration (Williams, 2007).

Retributivists see justice in the form of some legal "revenge" against those found guilty (Roche, 2007). This type of punishment would prevent acts of vengeance in the future, "thus breaking the cycle of violence" (Blewitt, 2008, p. 39) and potentially serve as the basis for a solid rule of law in the transformation stage. Without such catharsis, its advocates argue that is almost impossible to overcome the plagues of the past and to metamorphose toward a consolidated democracy.

Quite the opposite, restorative justice wants to make up and close the wounds of the past by restoring community ties and building a future based on a sense of commonness (Zehr, 2002). Thus, restorative justice, as one author puts it, seeks the "transformation of subjective factors that impair community, such as anger, resentment, and desire for vengeance" (Amstutz, 2006, pp. 166-167). Any response 
to such collective brokenness must seek to restore the basic fabric of society by including the victim, the offender and community members. Restorative justice principles, in general, have become the guiding moral force behind the development of truth commissions following mass murders, war crimes and other gross violations of human rights. Among some of the benefits of truth commissions are the elimination of a regime's ability to deny the truth, thus giving justice to the victims and making it easier to forgive and move forward toward possible reconciliation (Hayner, 2011, p. 22).

Last but not least, it is the concept of reparative justice. This concept centers on the recognition that human relationships have greatly suffered as a result of a type of regime or a particular conflict and these ties need to be repaired (Muddell and Hawkins, 2018). This is particularly relevant in countries that have suffered in their immediate past from genocide, war crimes, or other mass atrocities and need to undergo a process of catharsis. Thus, the repair is typically focused on trying to return the victim to their condition prior to suffering the violation to the extent possible. This cannot possibly be done without enforcing the rule of law and strong institutions that will be able to address the past objectively. On the other hand, as a caveat, we must stress that reparations programs do not typically build by themselves the rule of law or institutions.

Functioning institutions and greater accountability are highly conditional on the speed and quality of the democratization process. A fast and unequivocal transition from authoritarian rule and planned economy toward liberal democracy and a free market economy generates a priori the need for stronger constitutionality and rule of law; otherwise, the democratic reforms will fail to take off. Thus, transitional justice is important to understand, measure, and evaluate how it impacts democracy and democratization processes. Indeed, for many of these studies, the attainment of a liberal democratic regime that respects civil and political rights is the main indicator of success.

Early and swift forms of addressing the past are relevant for democratic consolidation because, without a general catharsis and reflections on dictatorships and their crimes against individual freedoms and human dignity, society cannot function normally and progress will be hard to achieve. A scholar captured the importance of particular transitional justice mechanisms, when he noted that "noncriminal sanctions, such as purges, lustration, and public access to security files, are critical for the democratic reform element..." Kritz (1999, pp. 19-20). It is, therefore, the contention of this paper that without quick and successful implementation of transitional justice that addresses the dictatorial past, the transition will suffer setbacks and democratic consolidation cannot be achieved. Thus, without a social pact that takes into account the entire legacy of the past, society simply cannot move ahead. Without accountability, there cannot be forgiveness. This is why it is important to take into account transitional justice 
measures as important variables in studying the shape of democracy in postauthoritarian societies.

\section{Transitional justice and democratic consolidation in post-communist eastern Europe}

Outside Stalinist Soviet Union, totalitarian Albania and the totalitariansultanic regime of Ceausescu's Romania were the most brutal (Stepan and Linz, 1996). However, recently 70 percent of present-day Russians have expressed support for Stalin's regime and feel nostalgic (Arkhipov, 2019), while Romania and Albania are the two countries with the highest negative views toward the former regime in Eastern Europe (Kajsiu, 2016). This is why I use Mill's Method of Difference to analyse these two very similar cases in most regards but they differ when it comes to the degree of democratic consolidation. These two countries, in addition to their common views toward both democracy and the former regime, have other resemblances as well such as pre-communist legacies, a relatively slow transition toward a market economy, initial problems of state-building, etc.

The variable where they most differ is the degree of democratic consolidation. While Romania is recently considered a semi-consolidated democracy but fully free society according to Freedom House's 2018 Report, with a total score of 3.46, Albania's democratization and its slow transition are among the most problematic in former communist Central and Eastern European countries (Elbasani, 2004; Kalemaj, 2016). While Romania joined the European Union in 2007 and has completed most of the necessary reforms to successfully make the transition toward consolidating democracy and a fully functioning market economy, Albania is still lagging. Albania has yet to open the negotiation chapters with the European Union, while it is currently in a political deadlock and suffers from non-functioning institutions (i.e., the highest courts) and a weak rule of law.

The speed of transition and democratization processes in East and Central Europe ranges from laggard Albania to successful Slovenia and Estonia. It seems that Estonia is a fully consolidated democracy with low transitional justice indicators, as the table below puts together a typology of interaction of the transitional justice measure and impact on democratization in CEE countries. Others, such as the Visegrád countries, that seemed early on well suited for rapid democratization and a smooth transition, now seem to be struggling with the democratization processes. My hunch is that transitional justice could be one of the missing links to understand why some countries reach faster democratic maturity than others. However, I see this relationship in correlational rather than causal terms in CEE countries. See the table below for an illustration of how former Eastern European countries have implemented different scales of transitional justice measures and the various levels of democratic consolidation that they have achieved. 


\section{Table 1. Implementation of transitional justice and different levels of democratization}

\begin{tabular}{l|l|l}
\cline { 2 - 3 } & \multicolumn{2}{c}{ Democratic Consolidation } \\
\cline { 2 - 3 } Holistic/Highly Regarded & East Germany & Low \\
& Czech Republic & Romania \\
& Bulgaria \\
\hline TJ & Estonia & Albania \\
Low & Slovakia & \\
\hline
\end{tabular}

Source: Author's representation

There is an ever-growing body of literature about transitional justice in Eastern Europe. One of the best collections to date is that edited by Lavinia Stan (2009) which takes into account successful and unsuccessful cases, as it pertains to policy intentions and degree of implementation. Just as this third wave of transitions in CEE varied a lot from country to country, transitional justice has varied as well. While some countries made rapid progress on democratization, especially in the first decade and a half after the fall of communism, some have recently slid back. This despite successful European integration of some of those countries, while others have stayed put such as the Western Balkans. ${ }^{2}$

Most of the former Eastern European countries have passed some variants of lustration laws by 1996 (Nalepa, 2010). Poland was among the first of the Visegrád countries to pass such a law in 1992 but it was declared unconstitutional and it had to pass a modified version in 1996. The Czech Republic did not establish courts like elsewhere but it enacted a blacklist of former security agents and collaborators and forbade them to hold public positions in the aftermath of communism as soon as 1991 (Ellis, 1996). East Germany was by far the outlier in the group of CEE countries because it was absorbed by West Germany, which in turn produced high political accountability and thorough processes of lustration, as well as other retributive, restorative, and reparative transitional justice components. This is a case in point of how early and successful implementation of transitional justice measures affects democratic consolidation.

Romania, on the other hand, although it failed to "enact radical lustration and court trials have been few in number and deficient in procedure" (Stan, 2009), it nevertheless has strongly condemned via the highest authority of the state, the

\footnotetext{
${ }^{2}$ For example, Hungary recently has been having a lot of problems with democratization and the recent measure by Freedom House makes Hungary the first and the only EU country that has moved backward from a consolidated free democracy to a partly free democracy (Freedom House, 2019). It has also moved backward on political accountability and dealing with the communist past in a fair and transparent manner, with the Orban government going as far as to rehabilitate some communist figures and removing some commemorations and memorials that were honoring communist victims.
} 
atrocities of the communist regime, after a report from the Presidential Commission for the Analysis of the Communist Dictatorship in Romania ${ }^{3}$, thus differentiating itself from most of its neighbours. But Romania has long suffered from a slow start and rather late democratization, making the first real transition of power from (former) communists to opposition only in 1996 (Marginean, 1997). Some authors even argue that "Romania has yet to fulfil its second democratization wave" (Craciun, 2017), while still starting to enact slowly at first and then rapidly its transitional justice measures, which helped rebuild the social fabric in a country that came a long way from a totalitarian past. I develop the Romanian case in full below. Bulgaria has a lot of similarities to Romania's case, with consecutive governments pushing hard transitional justice measures, such as lustration but being simultaneously criticized by a human rights group as violating individual rights by shifting the blame to collective guilt. ${ }^{4}$ Also, Bulgaria shares the same democratic features as Romania in most respects. ${ }^{5}$

\subsection{Transitional Justice in post-communist Romania}

This chapter examines the effects of transitional justice mechanisms in democratic consolidation in post-communist Romania. Romania implemented early on some vigorous retributive justice mechanisms such as state and opinion (popular) trials, ${ }^{6}$ restoratives such as active truth commissions (Stan, 2009) ${ }^{7}$, and rehabilitation and financial compensation as reparative means to address the needs of past prisoners and the formerly persecuted.

In the Romanian case, we notice a gap between the civil society's urges to have a clean break with the past and the political class' lack of willingness to implement the appropriate transitional justice mechanisms that would address that need in the first place. This also involves the role of institutions and how they have often succumbed to political interferences. Stan wraps this up neatly when

\footnotetext{
${ }^{3}$ Vierita, A. (2012), Romania's Communist Past (retrieved from https://www.nytimes.com/ 2012/03/05/opinion/romanias-communist-past.html).

${ }^{4}$ On the other hand, Helsinki Watch criticizes the Bulgarian government of pushing too far on its decommunistization activities and lustration measures because "the Constitutional Court's decision upholding the Panev Law will encourage increased efforts to purge former members of the Bulgarian Communist Party from important positions in academia". See: https://www.hrw.org/sites/default/files/reports/BULGARIA938.PDF.

5 Ranked partly free by Freedom House, scoring an overall 80 out of 100 . See: https://freedomhouse.org/report/freedom-world/2018/bulgaria.

${ }^{6}$ Opinion trials were different from state trials, complementary to them and particular only to Romania's case.

7 "Since the start of the democratization process in the early 1990s, only Germany, Estonia, Latvia, Lithuania, and Romania have employed truth commissions as methods to reckon with communist crimes" (Stan, 2009).
} 
accounting for the Tismăneanu Commission, created at the time by President Basescu, which included several civil rights groups and completed a scientific report that detailed the crime of "1945-1989 period in a systematic and dispassionate manner" (Stan, 2009, p. 25).

Tribunals that dealt with communist crimes, their perpetrators, and their collaborators have been a feature of the different degrees of implementation by all former Communist countries. They are often compared by the level of success of how much a role they had played for a swift and successful transition and how well a country democratized. In Romania, we note a particular type of tribunal, the socalled "Opinion Tribunals". They were another characteristic of Romania's citizens trial, which resembled such trials created elsewhere in the past (Klinghoffer and Klinghoffer, 2002) ${ }^{8}$ responsible for holding the former regime responsible for crimes against humanity although unfortunately, these trials received little notice from Romanian society or its citizens living abroad. They were mostly symbolic and lacked "legal standing", so they achieved very limited success, as Stan (2012) explains.

Regarding the overall lustration attempts and success, Romania started relatively late, only in the second half of the 1990s (Stan, 2013) and did not do enough to classify as one of the successful cases of former Eastern Europe. As the same author argues: "civil society has promoted lustration without convincing political elites to fully implement it." (Stan, 2013). However, civil society often compensated for a lack of enthusiasm from the political class in pushing for and promoting transitional justice measures.

On the other hand, Romania initially had an active political prisoner's association that with time started to falter. "Asociaţia Foştilor Deţinuţi Politici din România, constituted in 1990 in Bucharest, had branches throughout the country and a membership that reportedly diminished from 98,700 in 1990 to 45,000 by 2000 " (Stan, 2013). This has often been the case in other CEE countries and variables such as time, age, and political divisions have all been instrumental in the failure to sustain political momentum. On behalf of this alliance of former political prisoners, Senator Constantin Ticu Dumitrescu has said that:

[it] promoted lustration through his Bill on Access to Files and Unveiling the Securitate as a Political Police which permitted citizens to read the secret files compiled on them by the Securitate and asked public officials and electoral candidates unveiled as former secret agents to give up their posts or renounce the electoral race. After bitter debates, Parliament stripped the bill of its lustration stipulations. When the bill was adopted as Law 187/1999,

\footnotetext{
${ }^{8}$ This study compares and contrasts "the history of such 'citizens tribunals' from this first astonishing success to the mixed record of subsequent efforts - including tribunals on the Moscow show trials, the American war in Vietnam, Japanese sexual slavery, the Chernobyl nuclear disaster, etc.” (Klinghoffer and Klinghoffer, 2002).
} 
Dumitrescu was so dissatisfied with the changes operated by the house that he refused to accept the text's paternity (Stan, 2013).

The most successful period regarding the calls for the necessity of lustration in Romania was between 2005-07, where the Liberal-Democrats ruled the country. As Stan recalls:

[...] inspired by Bulgarian efforts, in 2006 Romanian journalists launched a Clean Voices campaign to identify secret agents from among television reporters, press contributors, and talk-show hosts. In response, Liberal legislators presented a lustration bill, the opposition lodged its own antinomenklatura legislative proposal, intellectuals, academics, and civil society representatives called on former and current spies to unveil their ties to communist and post-communist intelligence services, and many politicians admitted to past collaboration or were unmasked as former spies. More importantly, civil society groups convinced the Chamber of Deputies leaders to jointly organize a public debate on "Lustration: Principle or Instrument" on 25 May 2006. Besides legislators and ordinary citizens, representatives of 10 civil society groups - including the Timişoara Society, the Civic Alliance, and the Association of Former Political Prisoners - stated their position on this important transitional justice practice. (2011)

Thus, Romania had a strong civil society vocation for lustration and other forms of a radical break with communist pasts, but initially there was little political will to see through the enactment of legislation or to pursue real trials that would consistently ban from office former nomenklatura members and other transitional justice mechanisms. Below I expand on these transitional justice measures in Romania's case.

\subsection{Romania's transitional justice measures}

Romania's trials opened up with the show trial of former dictator Nicolae Ceausescu and his wife Elena that ended up with their summary execution. The last trial in Romania is against Ion Iliescu, the former communist-turned-socialdemocrat, responsible for the trial against Ceausescu, who in April 2019 is being charged with crimes against humanity for events that took place in 1988, together with deputy Prime Minister Gelu Voican Voiculescu and former Air Force Cdr Iosif Rus. ${ }^{9}$ The trials against former members of the communist nomenklatura began in 1989. Civil society from those earlier days was very much supporting and making calls for such swift trials as a clean break with the immediate past and a way to go forward with establishing rule of law. For example, as early as 1991, "the

\footnotetext{
${ }^{9}$ Ion Iliescu: Romania's ex-leader charged with crimes against humanity, 8 April 2019 (retrieved from https://www.bbc.com/news/world-europe-47858664).
} 
Association of Former Political Prisoners submitted to prosecutors a list of notorious communist perpetrators, including the deputy head of the Securitate Alexandru Nicolschi and Minister of State Security Alexandru Drăghici. In 1998, the name of Gheorghe Crăciun, former head of the Aiud prison (1958-1964), was added to the list. All three accused died before the courts heard their cases" (Muraru, 2011). The civil society umbrella group "Civic Alliance" called as early as March 1991 in its "Declaration on National Reconciliation," that "the Communist Party leaders, not all of the four million party members, should be considered morally responsible" for communist crimes. Whereas "any reference to a person should include his/her actions, not mere party membership, former Central Committee members, party activists, and Securitate agents should be banned from occupying public positions until the year 2000" (Ştefănescu, 1995, pp. 130-131). Below is a schematic view of the transitional justice measures that Romania undertook during its democratic transition phase.

Table 2. Summary of competing theories in transitional justice and their main instruments in Romania

\begin{tabular}{ll}
\hline Theory & Prediction \\
\hline Retributive & $\begin{array}{l}\text { State and Opinion (Popular) Trials in the post-communist period. } \\
\text { Vetting of former officials half-hearted. Backed by civil society but } \\
\text { not fully implemented by the political elite }\end{array}$ \\
\hline Restorative & $\begin{array}{l}\text { Strongly emphasized in political discourse. Active Truth } \\
\text { Commissions }\end{array}$ \\
\hline Reparative & $\begin{array}{l}\text { Rehabilitation and Financial Compensation that started rather late } \\
\text { but still continues }\end{array}$ \\
\hline
\end{tabular}

Source: Author's representation

As the table above indicates, in addition to both state and popular trials, Romania undertook restorative measures such as its Truth Commission, established in the second decade of the 1990s (Stan, 2012). It did also take reparative ones, such as rehabilitation and financial compensation that started as early as 1991 and continue to the present day.

\subsection{Democratic Consolidation in the Case of Romania}

But when it comes to democratic consolidation, Romania is shown to be much more robust than Albania and to have achieved it with relative speed. Although it is not the shining star among CEE countries, together with Bulgaria it joined the European Union in 2007, after failing to do so in 2004 when the other ten CEE countries joined simultaneously in the biggest EU expansion to date.

Romania has an Aggregate Freedom Score of 83 out of 100 for the year 2020 (Freedom House, 2020) and it has been constantly and persistently improving 
throughout the years. It has a rank of 69 out of 180 from Transparency International regarding corruption perception, including political corruption that is strongly linked to the quality of democracy and is just a bit above the EU-28 average of $66^{10}$, which in itself is one of the world's best regional averages, although as TI warns in its latest report it "still has a long way to go to tackle corruption effectively."

Romania's role as the chair of the EU Presidency for the first half of 2019 has brought much visibility, higher scrutiny, and additional accountability to the country. ${ }^{11}$ In addition, the police and prosecutor's offices tackle much more effectively corruption and organized crime than before and rule of law seems to be further consolidated after the arrest of Liviu Dragnea, the leader of the ruling party $\mathrm{PSD}^{12}$, and the recent confirmation of its former National Anticorruption chief Laura Codruta Covesi as the new European Chief Prosecutor. ${ }^{13}$

The difference is obvious if we compare Romania or Bulgaria with their counterparts in the Western Balkans. Currently, all Western Balkan countries suffer to some degree from some common symptoms such as corruption, state capture, and organized crime (Pejić, 2019). They all have little true independence of the judiciary, problems with property titles (Vesnic-Alujevic, 2012), inefficient public administrations (Durovic and Stojanović, 2016), and little political transparency (Kalemaj, 2016). A wave of political protests is currently taking place in Podgorica, Belgrade, Tirana, and Pristina. Thus, there is a big gap between consolidated democracies such as Romania and still transitioning countries such as Albania.

\subsection{Transitional Justice in Post-communist Albania}

Transitional justice in post-communist Albania is a topic often overlooked and yet under-researched. One of the few pieces to address the failure of an adequate transitional justice process in post-communist Albania has been by Austin and Ellison (2008) where they argue that the three main factors that rendered such process a failure, were the country's political culture, the impact of the communist regime, and most importantly "the lack of political will from Albanian political leadership to break away from its communist past". They insist that the country failed particularly with the lustration process, which the ruling class considered "as the political means to crush the opposition and consolidate its power." Thus, lustration that was not done for the

\footnotetext{
${ }^{10}$ Transparency International Albania (2020), https://www.transparency.org/country/ALB

${ }^{11}$ For example, the recent backtracking from judicial reform after strong criticism from Brussels (retrieved from https://www.dw.com/en/eu-warns-romania-against-plannedjudicial-reforms/a-42294820-0).

12 Romania's ruling party leader jailed for corruption, DW, 27 May 2019 (retrieved from https://www.dw.com/en/romanias-ruling-party-leader-jailed-for-corruption/a-48902823-0).

${ }_{13}$ New European Parliament supports Romania's Kovesi for European Chief Prosecutor, Romania Insider, 19 July 2019 (retrieved from https://www.romania-insider.com/epreaffirms-support-kovesi).
} 
purpose of a clean break with the past, holding responsible the perpetrators and achieving a catharsis that would allow the traumatized society to move ahead, but used by the political elite as a political and selective way to get rid of political opponents while consolidating their own power. For the authors, this led to the "transitional justice process in Albania becoming highly politicized and was used by politicians for political gains, which ultimately led to loss of trust from general public failing to detach the Albanian political scene from its communist past" (Austin and Ellison, 2008). Therefore, as I argue in a recently published piece, Albania has yet to complete "a credible, uncontested and complete lustration process that would mark the final divorce with the communist past and bring decommunization of society, the purification of political representation, the cleansing of the public administration and the judicial system, and a general catharsis that instils added value in the public discourse by setting forth contemporary ideas and not dealing with the past of certain individuals (Kalemaj, 2020).

Furthermore, Albania stands in stark contrast even with its closest neighbours that share a common past, given the different post-communist trajectories where the Yugoslavs were involved in identity-building and ethnic conflict wars that seem to be missing in neighbouring Albania. Albania has historically been a country of such paradoxes. Like the fact that it had the most difficult transition to democratic consolidation although it had a mono-ethnic society and did not get involved into irredentist and secessionist ethnic conflict of neighbouring Yugoslavia (Kalemaj, 2014).

Regarding transitional justice, Albania is neither the best-case scenario nor the worst. Civil society, media, and active citizens have been in the forefront as compared to the political class, which often for petty reasons or conflict of interest has generally been the main obstacle to a fast and completed transitional justice process. In general, as compared to Romania, Albania has shown itself to be much less active. there is no publicly recorded instance of civil society in Albania systematically pushing consecutive Albanian governments to establish transitional justice mechanisms. The difference is that while in Romania it is mostly a bottomup push for such reforms, emerging chiefly from civil society groups and networks, in Albania has generally been a top-down undertaking, given the structural weakness of civil society actors and the politicization of the debate regarding the adoption and enforcement of such measures. ${ }^{14}$

Among the measures that Albania has undertaken, a striking one has been the rehabilitation and financial compensation of former prisoners that started in 1991, immediately after the fall of the communist regime but due to limitations of financial

\footnotetext{
${ }^{14}$ When it comes to lustration measures in particular, both countries fell short in comparison with other CEE countries (i.e., Czech Republic or East Germany), but even among the Visegrád countries there were huge disparities. For example, "[w]hile in the Czech Republic 10,000 people lost their positions because of lustration in Hungary and Poland less than 500 were affected" (Stan, 2009).
} 
resources, continues to this day. Regarding some of the late measures, we can mention the vetting of former Sigurimi officials and collaborators that has only started in recent years. These former officials and collaborators have to pass the filter of the Authority of Dossiers before they can be elected or appointed in state positions.

One of the paradoxes in the Albanian case is that right after communism, some quick trials of former members of the nomenklatura, gave senseless sentences based on ridiculous charges (Beshiri, 1998). For example, the court condemned Hoxha's wife and Politburo members in the so-called "coffee trials", for financial misappropriation of food and drink funds for Politburo members, rather than condemning them for crimes against humanity, etc. This was corrected later, in 1996 with the Genocide Law, they were condemned for a second time. ${ }^{15}$ For supporters that was the real crime, while for critics they were politically motivated charges (Beshiri, 1998). Thus, they were purged in early post-communism years because they represented the dictatorship. Most of them anyhow benefitted from the 1997 amnesty.

On the other hand, commemorations have taken place regularly, though much more is expected to purge textbooks from ideological lenses and include that part of the population that was unjustly treated.

Albania also suffered from very limited trials that took place only in the aftermath of the communist regime, lack of real apologies, lack of lustration, etc. As one of the earliest examples of restorative justice in the Albanian case was the apology of former President Berisha, immediately after the fall of communism, in the very first year of transition: "We are all guilty and we all suffered"16. It was often quoted by critics from the right that emphasized that not enough was done in this earlier period to break the ties with the totalitarian past, as well as from the left that saw such declarations through an ideological prism. Another example of restorative justice in Albania is the truth commissions, but with very limited success as a transitional justice instrument influencing the democratization process. The Albanian truth commission, the Bezhani Commission, which replaced the previous Mezini Commission, had as its main goal to open the dossiers of high-ranking members of the past administration and to prevent them from holding elected offices during the democratic transition. In fact, it was highly contested and somewhat sabotaged from its inception. ${ }^{17}$ As a recent article has argued based on a comparative

\footnotetext{
15 The Genocide Law was specified only for very high-ranking members of the regime, starting with deputy ministers and above.

${ }^{16}$ Berisha, S. (2018), Pse ishim bashkëfajtorë dhe bashkëvuajtës, Rilindja Demokratike (retrieved from http://www.rd.al/2018/02/berisha-pse-ishim-bashkefajtore-dhe-bashkevuajtes/).

${ }^{17}$ In an interview given shortly before passing away, in June 2004 for German media "One Word Southeast Europe," Nafiz Bezhani takes pride in removing from offices 104 highranked politicians and bureaucrats, but he also warned about 56 tapes that were burned and hundreds of dossiers either lost, stolen or misplaced, never to be found (see more
} 
study, with the sole exception of Chile and South Africa, there is very little evidence for truth commissions contributing to successful democratization overall (Brahm, 2019). Albania could not have possibly been the exception to the rule, given also its overall obstacles, chief among which was the high political antagonism that has accompanied its troubled transition (Kalemaj, 2017).

Regarding reparative mechanisms, Albania undertook rehabilitation first through the Amnesty Law in 1991. After the hunger strike of the politically persecuted prisoners, the subsequent Innocence Law acquitted these (former) prisoners of any false charge based on their ideological leanings. But Albania never applied any form of property restitution for former political prisoners, the reason being the application of the new 7501 Law that distributed the land equally. Among other reparative measures of importance undertaken was financial compensation through government-issued securities (alb. letra me vlerë), which soon become worthless but, in the beginning, could serve for privatization of some public enterprises.

On the other hand, the verification trials as they were called, were to certify the real sufferers of conscience under the former regime and ways to compensate them. But it was applied unevenly due to different categories of former politically persecuted persons. First, for those executed with a court decision, the family would benefit from financial compensation. The second was the category of political prisoners. The third was the category of people shot without a court order, after identification of bodies and data obtained from family members and witnesses. In any case, we are talking only of financial compensation, but not property restitution.

Table 3. Summary of competing theories in transitional justice and their main instruments in Albania

\begin{tabular}{ll}
\hline Theory & Summary of what happened \\
\hline Retributive & $\begin{array}{l}\text { Limited Trials in immediate post-communist years } \\
\text { Vetting of former officials just starting (as we speak) }\end{array}$ \\
\hline Restorative & $\begin{array}{l}\text { Mostly rhetorical in the level of political discourse. } \\
\text { Truth Commission }\end{array}$ \\
\hline Reparative & $\begin{array}{l}\text { Rehabilitation and Financial Compensation that started in 1991 and } \\
\text { continues (also included treasure bonds/securities). } \\
\text { Lack of property restitution. }\end{array}$ \\
\hline
\end{tabular}

Source: Author's representation

As the table above illustrates, Albania has only partially undertaken transitional justice measures. Regarding the retributive mechanisms' Albanian governments in the first half of the 1990s have undertaken a few trials that were either symbolic like the "coffee trials" mentioned earlier or had a short lifespan like

https://www.pressreader.com/albania/gazeta-shqiptare/20141211/281672548278426). 
the "genocide" trials that gave a few harsh punishments but the perpetrators were soon amnestied by the subsequent government in 1997.

On the other hand, the vetting of the former collaborators of state security has just started, three decades after the fall of communism and the starting of the transitioning process. It is being done primarily for the party candidates that seek to enter the parliamentarian candidate lists in a more thorough and systematic way than the attempts of the "Mezini" and "Bezhani" ad hoc commissions of the 1990s.

Moreover, there is scarce evidence and no real political will for any degree of restorative justice, while reparative justice measures such as rehabilitation and financial compensation have received only scant attention from politicians during the entire transitioning period.

\subsection{Albania's yet to be completed democratic consolidation}

Albania is a clear case of un-consolidated democracy. Albania fails the test of democratic consolidation even when measured by regional standards. Albania currently ranks as a partly free country with a hybrid democracy according to the Freedom House index. It has an Aggregate Freedom Score of 67 for the year 2020 (Freedom House, 2020), while it has further worsened in some indicators, such as corruption. For example, in the last Transparency International Report, Albania slid back in the ranking and now occupies place 104 among 180 countries with a poor score of only 36 out of $100^{18}$. Even more dramatically, it has dropped 21 places in the last three years. These reports have continuously specified political corruption as a "serious and ongoing problem" in the country.

From its inception, Albania has had a "rocky road to democracy" (Biberaj, 1999). This can be at least partly explained through the disproportional impact that the former communist past had in impacting the country's political culture and as result its democratization trajectory, as compared to its post-communist experiences (Pop-Eleches et al., 2017). Actually, the former had strongly impacted the latter, especially in the first decade of transition. As I have argued elsewhere, four factors held back Albania's successful democratization, namely its totalitarian past, weak political and institutional culture, a fragmented economy not able to withstand the international market pressures, and the absence of rule of law due to widespread corruption in the judiciary, which normally would serve to correct the executive and legislative excesses (Kalemaj, 2016).

One of the factors that has had the highest impact is the elite struggles, manifested through constant and bitter political clashes. This political warfare has kept the institutional reform in limbo and the economy in the hands of oligarchs who have direct access to the political elite. There is little chance for national consensus

\footnotetext{
${ }^{18}$ Transparency International Albania (2020), (retrieved from https://www.transparency.org/ country/ALB).
} 
even when it comes to agreeing on national agendas, such as reforms to speed up European integration. Albania has not yet opened the negotiating chapters with the European Union seven years after signing the candidate status, while it took both Serbia and Montenegro only two years each to accomplish this process. Albania currently is in the worst political stand-off of the post-communist era, with Albanian opposition parties walking out of the parliament and burning their mandates, after accusing the government of stealing the last elections through the use of drugtrafficking money. At the same time, the government organized the June 2019 elections as if nothing had happened and the country is currently torn between the two camps. Thus, we may safely conclude that different from CEE countries, such as Romania or Estonia, Albania's democracy is yet to reach the stage of democratic consolidation.

\section{Conclusion}

The intention of this paper was to understand the effects of transitional justice measures on democratic consolidation in post-communist societies. It did so through a review of transitional justice measures and how they were adopted in the former Eastern European countries, while focusing particularly on the Romanian and Albanian cases, trying to understand the impact of such measures on democratization processes. Overall, adopting transitional justice measures early on and efficiently has resulted in faster democratic consolidation.

This study is important in several ways. Theoretically, it provides a model to understand the role and effect of transitional justice measures in post-communist CEE countries and how these measures have affected the speed and success of transition toward democratic consolidation. Empirically, by focusing upon the examples of Romania and Albania, we can better grasp the effects and nuances of different transitional justice measures and how they have impacted the shape of democracy writ large in these countries. Also, from a policy-making angle, this is important because it shows that the adoption of various transitional justice measures can have different results, especially when we discuss post-communist societies, which have a different trajectory from post-conflict or post-junta examples.

The former communist Eastern European countries have adopted different transitional justice measures as well as have had different results in their democratization efforts. Looking at these two interesting trajectories by trying to understand how the former has affected the latter, has opened up new avenues of research. While this study contributes to this emerging literature, it has its limitation because of the small number of cases explored. Nonetheless, by looking through comparative lenses the Romania and Albania cases, it opens up the opportunity for "Large-N" studies that will trace these patterns in a larger selection of cases.

Acknowledgement: This work was supported by a researcher's grant of the OSCE and the Konrad Adenauer Siftung (Albania office). I thank Eric Wiebelhaus-Brahm 
for his feedback on the earlier draft of this piece and two anonymous peer reviewers for their constructive ideas that strengthened this article.

\section{References:}

Acemoglu, D. (2014), Does Democracy Boost Economic Growth?, World Economic Forum (retrieved from https://www.weforum.org/agenda/2014/05/democracy-boosteconomic-growth/).

Amstutz, M.R. (2006), Restorative Justice, Political Forgiveness and the Possibility of Political Reconciliation, in: Philpott, D. (ed.), The Politics of Past Evils: Religion, Reconciliation, and the Dilemmas of Transitional Justice, Notre Dame: University of Notre Dame Press.

Aoláin, F.N. and Campbell, C. (2005), The Paradox of Transition in Conflicted Democracies, Human Rights Quarterly, pp. 172-213.

Arkhipov, I. (2019), Russian Support for Stalin Surges to Record High, Poll Says, Bloomerg, and 15 April (retrieved from https://www.bloomberg.com/news/articles/2019-0416/russian-support-for-soviet-tyrant-stalin-hits-record-poll-shows).

Arnould, V. and Sriram, C.L. (2014), Pathways of impact: how transitional justice affects democratic institution-building, TJDI Policy Paper (retrieved from https://www.egmontinstitute.be/content/uploads/2014/10/TJDI-Policy-Paper-

Pathways-of-Impact1.pdf?type=pdf).

Aukerman, M.J. (2002), Extraordinary Evil, Ordinary Crime: A Framework for Understanding Transitional Justice, Harvard Human Rights Journal, 15(39), pp. 29-98.

Austin, R.C. and Ellison, J. (2008), Post-Communist Transitional Justice in Albania, East European Politics and Societies, 22(2), pp. 373-401.

Beshiri, D. (1998), Gjyqi i kafeve: procesi penal kundër të vesë së Enver Hoxhës, Tirane: Iliria.

Blewitt, G.T. (2008), The Importance of a Retributive Approach to Justice, in: Blumenthal, D.A. and McCormack, T.L.H. (eds.), The Legacy of Nuremberg: Civilizing Influence or Institutionalized Vengeance?, Leiden: Martinus Nijhoff Publishers.

Borer, A.T. (2006), Telling the Truths: Truth-telling and Peace Building in Post- Conflict Societies, Notre Dame: University of Notre Dame Press.

Brahm, E. (2007), Uncovering the Truth: Examining Truth Commission Success and Impact, International Studies Association, Maiden: Blackwell Publishing.

Brahm, E. (2021), Truth and Consequences: The Impact of Truth Commissions in Transitional Societies.

Brown, A. (1999), Russia and Democratization, Problems of Post-Communism, 46(5), pp. 313. https://doi.org/10.1080/10758216.1999.11655847

Craciun, C. (2017), Romania's Second Democratic Transition (retrieved from https://library.fes.de/pdf-files/id-moe/13080.pdf).

Dahl, R.A. (1971), Polyarchy: Participation and Opposition, New Haven: Yale University Press. 
de Brito, A.B., Gonzalez-Enriquez, C., Aguilar, P. (2001), The politics of memory: Transitional justice in democratizing societies, New York: Oxford University Press.

Diamond, L. (1999), Developing Democracy: Toward Consolidation, John Hopkins University Press.

Drumbl, M. (2007), Atrocity, Punishment, and International Law, New York: Cambridge University Press.

Durovic, G. and Stojanović, B. (2016), The optimization of Public Administration in the Western Balkans Region: Comparative Study with Baseline Analysis, Regional School of Public Administration, Montenegro: ReSPA.

Elbasani, A. and Lepinski, A. (2011), Public Contestation and Politics of Transitional Justice: Poland and Albania Compared, EUI Working Papers.

Ellis, M.S. (1996), Purging the past: The Current State of Lustration Laws in the Former Communist Bloc, Law and Contemporary Problems, 59(4), pp. 181-196.

Grosescu, R. (2017), Judging Communist Crimes in Romania: Transnational and Global Influences, International Journal of Transnational Justice, 11(3), pp. 505-524. https://doi.org/10.1093/ijtj/ijx016

Guo, S. and Stradiotto, G. (2014), Democratic Transitions: Modes and Outcomes, London: Routledge. https://doi.org/10.13140/2.1.3550.7845

Halmai, G. (2009), The Impact of Transitional Justice on the Democratic Consolidation in East Central Europe Transition and Democratization, Conference Paper, (retrieved from https://www.researchgate.net/publication/273450566_The_Impact_of_Transitional_Ju stice_on_the_Democratic_Consolidation_in_East_Central_Europe_Transition_and_D emocratisation).

Hayner, P. (2002), Unspeakable Truths: Facing the Challenges of Truth Commissions, London: Routledge.

Horne, C.M. (2012), Assessing the Impact of Lustration on Trust in Public Institutions and National Government in Central and Eastern Europe, Comparative Political Studies, 45(4), pp. 412-446. https://doi.org/10.1177/0010414011421766

Horne, C.M. (2017), Building Trust and Democracy: Transitional Justice in Post-Communist Countries, Oxford University Press Scholarship Online. https://doi.org10.1093/oso/9780198793328.001.0001

Huntington, S.P. (1993), The third wave: Democratization in the late twentieth century, Vol. 4, University of Oklahoma press.

Kajsiu, B. (2016), Polarization without radicalization: political radicalism in Albania in a comparative perspective, Journal of Contemporary European Studies, 24(2), pp. 280299. https://doi.org/10.1080/14782804.2016.1159545

Kalemaj, I. (2014), Contested Borders: Territorialization of National Identity and Shifts of “Imagined Geographies" in Albania, Peter Lang Ltd. Oxford 2014.

Kalemaj, I. (2016), Albania's democracy challenges: External stimuli and internal factors at play", Academic Journal of Interdisciplinary Studies, 5(3), pp. 107-107. https://doi.org/10.5901/ajis.2016.v5n3p107 
Kalemaj, I. (2020), Lustration in Albania: The past and the future, OSCE Presence in Albania (retrieved fromhttps://www.osce.org/files/f/documents/e/4/445090.pdf).

Kayser-Whande, U. and Schell-Faucon, S. (2008), Transitional Justice and Civilian Conflict Transformation, CCS Working Papers, No. 10 (retrieved from https://core.ac.uk/download/pdf/187128856.pdf).

Kritz, N. (2009), Policy Implications of Empirical Research on Transitional Justice, in: Van der Merwe, H., Baxter, V. and Chapman, A. (eds.), Assessing the Impact of Transitional Justice, Washington, D.C.: U.S. Institute of Peace.

Kuzio, T. (2002), National Identity and Democratic Transition in Post-Soviet Ukraine and Belarus: A Theoretical and Comparative Perspective, East European Perspectives, 4(15), pp. 1-27.

Lipset, S. (1959), Some Social Requisites of Democracy: Economic Development and Political Legitimacy, The American Political Science Review, 53(1), pp. 69-105.

Magara, I. (2016), Transitional justice and democratization nexus: Challenges of confronting legacies of past injustices and promoting reconciliation within weak institutions in Kenya, African Journal of Conflict Resolution, 6(1), pp. 9-34.

Marginean, I. (1997), Indicators of Democratization in Romania, Social Indicators Research, 42(3), pp. 353-366.

Merkel, W. (1998), The Consolidation of Post-Autocratic Democracies: A Multi-level Model, Democratization, 5(3), pp. 33-67.

Mill, J.S. (1843), A system of Logic, Vol. 1., London: John W. Parker.

Muddell, K. and Hawkins, S. (2018), Gender and Transitional Justice: A Training Module Series. Module 3: Reparative Justice, International Centre for Transitional Justice.

Nalepa, M. (2010), Skeletons in the Closet: Transitional Justice in Post-Communist Europe, Cambridge: Cambridge University Press.

O’Donnell, G., Schmitter, P.C., Whitehead, L. and Lowenthal, A.F. (1986), Transitions from Authoritarian Rule: Comparative Perspectives, Baltimore: Johns Hopkins University Press.

Pejić, J. (2019), “All Western Balkans Countries Need Priebe Reports" to Measure State Capture," European Western Balkans, 8 February (retrieved from https://europeanwesternbalkans.com/2019/02/08/priebe-report-state-capture-westernbalkans/).

Pop-Eleches, G., Tucker, J.A. and Tucker, J. (2017), Communism's Shadow, New Jersey: Princeton University Press.

Roche, D. (2007), Retribution and restorative justice, in: Johnstone, G. and Ness, D.W. (eds.), Handbook of Restorative Justice, Portland: Willan Publishing.

Rotberg, R.I. and Thompson, D. (2000), Truth v. Justice: The Morality of Truth Commissions, Princeton: Princeton University Press.

Saxonberg, S. and Jonas, L. (2003), Beyond Transitology: Area Studies Debate, Problems of Post-Communism, 5(30), pp. 3-16. 
Schelder, A. (1998), What is Democratic Consolidation?, Journal of Democracy, 9(2), pp. 91107.

Schumpeter, J.A. (2014), Capitalism, socialism and democracy ( $2^{\text {nd }}$ ed.), Floyd: Impact Books.

Stan, L. (2009a), Truth Commissions in Post-Communism: The Overlooked Solution?, The Open Political Science Journal, 2(1), pp. 1-13.

Stan, L. (2009b), Transitional Justice in Eastern Europe and the Former Soviet Union: Reckoning with Communist Past, BASEES/Routledge Series on Russian and East European Studies, London: Routledge.

Stan, L. (2012), Transitional Justice in Post-Communist Romania: The Politics of Memory, Cambridge: Cambridge University Press.

Stan, L. (2013), Civil Society and Post-communist Transitional Justice in Romania, Chapter 2, in: Simić, O. and Volčič, Z. (eds.), Transitional Justice and Civil Society in the Balkans, Springer Series in Transitional Justice, Springer Science+Business Media New York.

Stan, L. (2014), Determinants of Post-Communist Transitional Justice: An Overview, Paper prepared for the Global Challenges Conference Justice and Imagination: Building Peace in Post-Conflict Societies, Mount Holyoke College, February 28-March 1 (retrieved from https://www.mtholyoke.edu/sites/default/files/global/docs/Stan\%20paper.pdf)

Ştefănescu, D. (1995), Cinci ani din istoria României. O cronologie a evenimentelor decembrie 1989-decembrie 1994, Bucharest: Editura Maşina de Scris.

Stepan, A. and Linz, J. (1996), Problems of Democratic Transition and Consolidation: Southern Europe, South America, and Post-Communist Europe, Baltimore: Johns Hopkins University Press.

Stover, E. and Harvey, M.W. (2004), My Neighbor, My Enemy: Justice and Community in the Aftermath of Mass Atrocity, Cambridge: Cambridge University Press.

Teitel, R.G. (2002), Transitional Justice, Oxford: Oxford University Press.

Vesnic-Alujevic, L. (2012), European Integration of Western Balkans: From Reconciliation to European Future, Center for European Studies. Brussels: CES.

Wiebelhaus-Brahm, E. (2010), Truth Commissions and Transitional Societies: The Impact on Human Rights and Democracy, New York: Routledge.

Williams, K. (2007), Explaining lustration in Central Europe: a 'post-communist politics' approach, Journal of Democratization, 12(1), pp. 22-43. https://doi.org/10.1080/1351034042000317943

Zehr, H. (2002), The Little Book of Restorative Justice, Intercourse, PA: Good Books. 